\title{
Примож Трубар и его деятельность в трудах русских славистов
}

\author{
Marianna Leonidovna Beršadskaja \\ Saint Petersburg State University 7-9, Universitetskaya Nab., \\ Saint Petersburg, 199034, marber2@rambler.ru \\ Санкт-Петербургский государственный университет Россия, \\ 199034 г. Санкт-Петербург, Университетская наб. 7-9, marber2@rambler.ru
}

SCN I/1 [2008], 88-101

В статье рассматриваются русские исследования о деятельности П. Трубара, созданные в течение 180 лет, от »Библиографических листов« П. И. Кеппена, вышедших в 1825 г., до монографии петербургского исследователя А. С. Герда о словенском языке XVI века, опубликованной в 2005 году. Кроме того, в статье затронуты проблемы русско-словенских научных и литературных связей.

This paper reviews research work on P. Trubar by Russian scholars through 180 years, starting from P. E. Keppen's Bibliographic Leaves in 1825 up to a monograph published in 2005 by Saint Petersburg researcher A. S. Gerd on the $16^{\text {th }}$ century Slovenian language. The article also raises the issue of Russian and Slovenian scholarly and literary contacts.

Ključne besede: Деятельность П. Трубара в трудах русских славистов

Key words: P. Trubar's activities in works by Russian Slavists

Впервые имя П. Трубара было введено в научный обиход П.И. Кеппеном (1793-1864), известным русским славистом, библиографом, археографом, географом и этнографом, одним из учредителей в 1816 г. Вольного общества любителей российской словесности, активным членом Румянцевского кружка, сыгравшего значительную роль в развитии российской славистики.

Кеппен первым из русских филологов совершил длительное путешествие по Европе (1821-1824), заранее составив тщательно продуманную 
научную программу. Во время этой поездки он не только работал в музеях и библиотеках, изучал славянские древности и современные культурные достопримечательности, но и устанавливал личные контакты с учеными, писателями и общественными деятелями славянских народов - В. Караджичем, Е. Копитаром, П.Й. Шафариком, Я. Колларом, Й. Добровским, В. Ганкой и др. Кеппен чрезвычайно внимательно штудировал работы своих зарубежных коллег, знакомил их с книгами русских славистов, в свою очередь информируя русских ученых об их деятельности. Итогом этого путешествия было установление у Кеппена и - с его помощью - у многих членов Румянцевского кружка прочных научных и личных контактов с западноевропейскими славистами. Возвратившись из путешествия, Кеппен предпринял издание первого международного библиографического журнала »Библиографические листы« (1825-1826; всего за этот период вышло 43 номера), где печатались крупнейшие слависты России и Европы, давалась новейшая информация об исследованиях и открытиях в области славяноведения.

Формулируя цели издания, Кеппен писал: »Главное назначение сих листов состоит в том, чтобы сообщать полные заглавия новых книг, на разных языках в России издаваемых, и предлагать их краткое содержание... По части иностранной литературы предложатся известия только о важнейших предметах...«. ${ }^{1}$

Судя по всему, к числу таких »важнейших предметов«, т.е. тем, Кеппен относил судьбу старопечатных славянских книг, о которых говорилось в первом номере »Библиографических листов«. Перечню этих книг предшествовала статья Кеппена »Словенская [в данном случае »славянская« — М. Б.] литература«, в которой был дан обзор чешской, польской, хорватской и словенской средневековых литератур и литератур позднего средневековья. Кеппен говорит о той роли, которую сыграла деятельность Примаса Трубера (так он именует словенского реформатора) в развитии словенского и хорватского книгопечатания, в закладке основ словенского языка и словенской литературы. »Бескорыстной ревности Трубера, щедротам барона Унгнада и христианскому трудолюбию Георгия Далматина юго-западные славяне обязаны как переводом Священного Писания, так и вообще основанием своей словесности «. ${ }^{2}$. В перечне старопечатных славянских книг, опубликованном в нескольких номерах журнала, дается информация о 29 книгах, изданных славенскими реформаторами. »Богорич, - пишет Кеппен, комментируя список, - своею Грамматикою, изданною в 1584 г., утвердил правописание крайнское и до сего то времени (начиная с 1550 года) у нас доведен список первопечатным краинским книгам. После 1584 г. показана одна только книга, вероятно, последняя,

\footnotetext{
${ }^{1}$ Кеппен П. И. Предисловие//Библиографические листы, 1825, №1 (6.I). С. 2

${ }^{2}$ Кеппен П. И. Словенская литература// Библиографические листы, 1825, №1 (6.I). C. 7
} 
изданная в Тюбингене в 1595 г. Когда же напечатана и существует ли еще где-либо Труберова Formula Concordiae, нам не известно «. ${ }^{3}$

Таковы первые сведения о Трубаре и словенской Реформации, приведенные Кеппеном.

Дальнейшему знакомству русской общественности с деятельностью Трубара способствовал словенский ученый В. Клун, опубликовавший в первом славянофильском журнале »Русская беседа« две статьи. Первая из них — „Словенцы« - была напечатана в третьем номере журнала за 1857 год и описывала нравы и обычаи словенцев, современное положение словенского народа, стремящегося - по мысли автора - к единению со своими славянскими братьями. »Я только старался, - писал Клун, завершая статью, - и, надеюсь, успел ясно доказать, что словенцы даровитое и энергетическое племя, выступающее на поприще всемирной истории во всей силе юности с живым сознанием своей народности и с горячей любовью к вере. В этом убеждении смело и честно протягивают они дружескую руку соплеменным братьям, дабы единство духа и энергии привело всех к одной общей цели, дабы все мы слились в единую народную семью«. ${ }^{4}$

Вторая статья Клуна, опубликованная в »Русской беседе«, посвящалась истории словенской литературы от Фрейзингенских отрывков вплоть до начала XIX века. Клун выделял в развитии словенской литературы два периода - протестантский (XVI в.) и католический (с конца XVI в. до современной ему эпохи).

Оценивая словенскую Реформацию, Клун пишет: »XVI-ый век, столь замечательный во многих отношениях, был, вместе с тем, и началом пробуждения литературы и науки... до выступления на поприще Трубера не было ни напечатано, ни написано на словенском языке ни одного сочинения; и Трубер в предисловии ко второму изданию своего перевода Нового Завета (Тюбинген, 1582), имел полное право сказать: »За 34 года не было не только книги, даже письма на нашем виндском языке, ибо все считали виндский и венгерский языки самыми грубыми и варварскими и думали, что на них нельзя ни читать, ни писать«. ${ }^{5}$

Основная заслуга Трубара состоит - по утверждению Клуна — в том, что он »первый стал писать на словенском языке, — ввел латинские буквы и устроил в Любляне первую типографию. Такая заслуга, конечно, навсегда упрочит за ним благодарную память и почетное место на страницах истории словенской литературы«. ${ }^{6}$

\footnotetext{
${ }^{3}$ Там же. С. 7

${ }^{4}$ Клун В. Словенцы//Русская беседа, 1857, №3. С. 122

${ }^{5}$ Клун В. Словенцы. Очерк истории их словесности// Русская беседа, 1859, I (Четвертый год. Книга тринадцатая). С.100

${ }^{6}$ Там же. С. 105
} 
Восхищаясь Трубаром, которого он - повторяя слова Метелко - называет »словенским литературным Колумбом«. ${ }^{7}$ Клун, тем не менее, отмечает и отрицательные стороны деятельности Трубара. Рассматривая этот период, - пишет Клун - видим, что духовный обмен и литературное товарищество с Германией, хотя и пробудили у словенцев все стороны умственной жизни, но, вместе с тем, имели и ту невыгоду, что развитие с самого начала стало не народным и чужеземным. С этого-то времени и следует, главным образом, считать начало в Крайне преобладающего влияния германского элемента над славянским, которое, меняясь, но, не слабея, продолжается во всю последующую историю. Появление у нас немецкой стихии и постепенное вытеснение ею родной, славянской, - главною своею причиною имеют, может быть, именно этот первый научный дебют Крайны в XVI веке и необходимый тогда литературный размен с Германией«. ${ }^{8}$

Видимо, на оценку Клуна повлиял Копитар, упрекавший Трубара в »германизмах« и религиозном фанатизме. Клун приводит копитаровскую оценку деятельности Трубара: »Трубар, Далматин и Богорич принадлежали к религиозной партии, подавленной в здешней стране мощною волею Фердинанда II. Писателями Краинскими сделал их дух религиозного фанатизма (зелотизма); а от этого злого духа бегут свободные Музы. Первым отсюда следствием было то, что пренебреженные Музы отомстили за себя варваризмами, а вторым, что ненависть, гнавшая протестантскую партию, постигла и ея сочинениящ. ${ }^{9}$

Клун ни коим образом не комментирует высказывание Копитара; вероятно, он стремился сохранить некоторую беспристрастность в оценке конфликта между протестантизмом и католической религией. Восхищаясь реформами Трубара, он столь же уважительно писал о католическом духовенстве, уничтожавшем его книги.

Мы довольно подробно останавливаемся на высказываниях словенского ученого, поскольку эта первая подробная информация на русском языке оказала влияние на рассмотрение этих проблем русскими исследователями, в частности А. Дювернуа (1839-1886). Лингвист, специалист в области истории славянских культур, ученик О. М. Бодянского, Дювернуа закончил Московский университет и был оставлен при кафедре славянской филологии, которую впоследствии (в 1869 г.) возглавил.

В 1865 г. Дювернуа был на два года командирован за границу (Прага, Вена, Тюбинген, Берлин, Гейдельберг) для подготовки по сравнительной грамматике индоевропейских языков. Во время командировки Дювернуа уделял очень большое внимание рукописным архивным материалам, истории, литературе и искусству славян. Его отчеты по славистике, представленные в Университет по возвращении, были посвящены опи-

\footnotetext{
7 Там же. С. 101

${ }^{8}$ Там же. С. 112

${ }^{9}$ Цит. по ук. статье Клуна. С. 112
} 
санию старой чешской рукописи Яна Благослава и Тюбингенским актам славянской типографии в Вюртемберге. Последние он опубликовал в Московских университетских известиях за 1868 г.

Отдавая должное заслугам тюбингенского профессора А. Шнуррера, посвятившего этим материалам свою монографию »Slavischer Bücherdruck in Würtemberg in 16. Jahrhundert« (1799), Дювернуа отмечал, что »при всей точности и добросовестности сообщений Шнуррера... он был, естественно, чужд вопросов, внушаемых... в настоящее время современной историографией и славистикой«. ${ }^{10}$

Обзор Дювернуа дает весьма ценные сведения о полемике П. Трубара и М. Кломбнера вокруг перевода библейских текстов на словенский язык, о тех условиях, в которых пришлось жить и работать словенскому реформатору, о политических и конфессиональных хитросплетениях идеологической борьбы этого периода. Русский исследователь пишет о Трубаре и его борьбе с несомненной симпатией, в то же время он осуждает поведение его оппонента.

»Кломбнер, - пишет Дювернуа, - прикрывая ханжескими фразами личную ненависть к Трубару, старается выставить его как помеху успешному течению дела, себя же с ближайшими сотрудниками как первых его двигателей и страдальцев за правду. ${ }^{11}$

В свете вышесказанного несколько удивительным кажется финальный вывод Дювернуа, весьма вероятно, объясняющийся влиянием уже цитировавшегося высказывания Копитара. »Этим мы заключаем наше обозрение архивного наследия славянской типографии в Вюртемберге, - пишет Дювернуа. Оно раскрыло нам внутренние побуждения действующих лиц предприятия, осветило нам их цели и средства. Каждому известно, впрочем, что оно не было обильно плодами, замерло вместе с Унгнадом, которого на основании выше разобранных актов, не усомнимся признать и первым двигателем и душою предприятия. В чем же тайна этого неуспеха? $\mathrm{Ee}$, очевидно, нужно искать в недостатке внутреннего согласия и единства целей между соучастниками. Немецкому евангелическому проповеднику не оказалось возможным сделать целое славянское племя, окрепшее в родных преданиях, слепым орудием своих целей. ${ }^{12}$

Первой попыткой дать всесторонний анализ деятельности Трубара является монографическое исследование А.А. Соколова »Зарождение литературы у словенцев. Примус Трубер«, опубликованное в Киеве в 1878 году ${ }^{13}$

10 Дювернуа А. Л. Тюбингенские акты Славянской книгопечатни в Вюртемберге// Московские университетские известия. 1868, №4. С. 276

${ }^{11}$ Там же. С. 289

12 Там же. С. 315

${ }^{13}$ Исследование было напечатано в Киевских университетских известиях № 3 (март) 1878. С. 249-275; № 4 - апрель 1878. С. 277-329. Кроме этого были отпечатаны отдельные оттиски этой работы, по которой обычно и приводятся цитаты. 
А. А. Соколов (1848-?), лингвист и литературовед, закончил историкофилологический факультет Дерптского университета, затем слушал лекции по славистике в Московском университете, в 1876-1878 гг. находился в заграничной командировке (Прага, Загреб, Вена). В 1878 г. был утвержден в звании приват-доцента по кафедре славянской филологии в Киеве, с 1879 г. — приват-доцент Дерптского университета. В 1883 г. переехал в Варшаву, где стал директором гимназии.

Исследование о Трубаре стало первой крупной работой Соколова. Во вступлении автор мотивирует выбор темы следующим образом: »Словенцы... долгое время оставались как бы забытыми пасынками славянской науки... Из русских ученых, если не ошибаемся, первый обратил более серьезное внимание на них И. И. Срезневский, а в последнее время - казанский профессор Бодуэн де Куртенэ в своей прекрасной монографии о резианском говоре... Во всяком случае, остается еще громадный пробел — литература словенцев... «14

Стремясь восполнить этот пробел, Соколов во время своего пребывания в Вене досконально изучил все труды Трубара, находившиеся в Венской придворной библиотеке, обладавшей наиболее полным собранием сохранившихся изданий. Наряду с трудами Трубара, он проштудировал сочинения Вальвазора, Копитара, Шафарика, Добровского, Костренчича, Кукулевича-Сакцинского, Шнуррера, Силлема, Димица и др. Особе внимание он обратил на монографию Силлема, считая, что »труд Силлема и интересен, и составлен добросовестно и тщательно.$^{15}$ Вместе с тем, Соколов не согласен с утверждением Силлема о том, что труды Трубара способствовали усилению влияния немецкой культуры, поскольку »имели общекультурное значение, а отнюдь не были проводниками специально немецкой образованности«. ${ }^{16}$ Давая общую оценку деятельности Трубара, Соколов выражает свое несогласие с уже цитировавшимся выше заключением Дювернуа »о целях немецкого евангелического проповедникак. »Согласится с этим трудно, - пишет он, — ибо трудно понять, кого г-н Дювернуа подразумевает под »немецким евангелическим проповедником« и какие таинственные »цели« преследовал сей проповедник, коих »слепым орудием« он хотел сделать окрепшее в родных преданиях целое славянское [т.е. словенское - М.Б.] племя. Нам кажется, что славянское племя было слепым орудием в руках римской курии, всеми средствами уже несколько сот лет старавшейся окончательно отторгнуть это племя от его греко-славянских братьев.$^{17}$ Как видим, при рассмотрении деятельности Трубара наиболее дискуссионными являются два момента: вопрос о том, в какой степени распространение его идей способствовало усилению тенденций германизации словенской культуры, и конфессиональная со-

\footnotetext{
${ }^{14}$ Соколов А. Зарождение литературы у словенцев. Примус Трубар. Киев, 1878. С. 1

15 Там же. С. 4

16 Там же. С. 4

${ }^{17}$ Там же. С. 8
} 
ставляющая проблемы. Соколов отмечает историческую необходимость распространения идей Лютера в Словении, лишенной каких бы то ни было условий для развития национальной культуры. »Грустную картину, пишет ученый, - представляет словенское племя в описываемую эпоху: пастырей добрых - нет, школ - нет, книг на родном языке - и нет, и не бывало « ${ }^{18}$. Именно поэтому — считает ученый — „буря, воздвигнутая могучим словом Лютера«, нашла такой отклик в словенских землях. Он [Трубар - М.Б.] верил Лютеру на слово - и эта вера сделала его реформатором Крайны; он любил свой народ - и эта любовь сделала его первым (по времени) словенским писателем « ${ }^{19}$ - так Соколов определяет характер начинаний П.Трубара и подчеркивает, что к числу его заслуг относятся создание письменности и книг на »простом мужицком языке« родной ему Крайны, распространение переводов словенских богослужебных книг среди сербов и хорватов, издание книг на хорватском языке, создание школ и первой словенской типографии в Любляне, закладка основ первой словенской публичной библиотеки.

С нескрываемой горечью Соколов пишет о том, что в первой половине XVII в. на Реформацию в словенских землях обрушились жесточайшие карательные меры католической контрреформации; протестанты были преданы суду, их имущество конфисковано, книги сожжены, а типографии - уничтожены. »... Снова, - пишет исследователь, - подверглась унижению словенская народность, а язык - гонениям. И вот тут-то сказалась польза, принесенная Трубаром: и народность, и язык выдержали все удары судьбы; раз пробужденное сознание, что можно читать и писать на словенском языке, что он обладает достаточной внутренней силой, - это сознание, вызванное Трубаром, окрепшее благодаря трудам Юрия Далматина, Себастьяна Креля, Адама Бохорича, - не могло уже заглохнуть...«. ${ }^{20}$

Вскоре после публикации исследования Соколова в Журнале Министерства народного просвещения появилась рецензия на него, автором которой стал В.В. Качановский (1853-1901), молодой специалист по славянской письменности и истории, занимавший пост помощника библиотекаря в Варшавском университете. Впоследствии он был магистром этого университета, приват-доцентом кафедры филологии Казанского университета, преподавателем историко-филологического института в Нежине.

Подчеркивая новизну и важность избранной Соколовым темы, рецензент утверждал, что она оказалась слишком сложной для исследователя, ведь »даже бессмертным в словенской литературе Копитаром не стави-

\footnotetext{
${ }^{18}$ Там же. С. 8

19 Там же. С. 19

${ }^{20}$ Там же. С. 74
} 
лась задача осветить зарождение словенской литературы«. ${ }^{21}$ Соколову, по мнению Качановского, не удалось внести в разработку этой темы ничего нового. Единственное исключение - полемика автора с Копитаром, упрекавшим Трубара за употребление большого количества германизмов. Соколов утверждал, что это связано с особенностями словенского разговорного языка XVI в. и не является специфической чертой словоупотребления и стиля самого Трубара. Главный упрек, адресованный Качановским исследователю, плохое знание литературы по избранной теме: »После Копитара исследования о словенской литературе писали Дайнко (1824), Метелко (1825), Мурко (1843), Янежич (1851 и 1854), Клун и др. Эти словенские ученые, равно как и слависты других стран - И. И. Срезневский, Б. И. Шафарик, Фр. Миклошич и И. А. Бодуэн де Куртенэ - много расчистили путь, на котором нашему автору не могло представиться особенных затруднений. Г. Соколову предварительно следовало добросовестно проштудировать то, что сделано до него, хотя у него встречаются ссылки на главнейшие исследования по интересующему его вопросу. Оттого труд его страдает отсутствием ясного и определенного планащ. ${ }^{22}$

Кроме того, Качановский считал, что периодизация деятельности Трубара, предложенная Соколовым, является неубедительной, а филологический аспект исследования очень слаб. И характер упреков, и тон, которым они были высказаны, во многом представляются нам неоправданно критическими и несправедливыми. Допустим, какие-то источники ускользнули от внимания исследователя, но ведь и список проштудированных и использованных весьма внушителен. В исследовании прослеживается весьма четко план, хотя от него и имеются некоторые отклонения. Критикуя периодизацию Соколова, Качановский не предлагает альтернативных вариантов, упреки »в филологической слабости работы«не подтверждены убедительными доказательствами. Утверждая, что »в славистике уже имеются кое-какие труды и монографии« по вопросу, »занимавшему г. Соколова, и, притом, значительно вышестоящие, чем исследование нашего автора«, ${ }^{23}$ - Качановский не приводит ни одного конкретного имени или названия труда, что делает его утверждение голословным. Очень жаль, что труд Соколова стал не предметом доброжелательной конструктивной критики, а объектом жестокого немотивированного разгрома. Вероятно, это было причиной того, что А. Соколов больше не возвращался в своих трудах к деятельности Трубара.

Немалая заслуга в исследовании словенской Реформации принадлежит выдающемуся ученому, историку культуры, литературоведу, публицисту, этнографу и археографу А.Н. Пыпину (1833-1904). Выпускник Санкт-

\footnotetext{
${ }^{21}$ Качановский В. В. Заметки о словенском языке 15 и 16 вв. Зарождение литературы у словенцев. Примус Трубар//Журнал Министерства народного просвещения, 1878 №9. С. 101

${ }^{22}$ Там же. С. 101

${ }^{23}$ Там же. С. 118
} 
Петербургского университета, он был профессором кафедры истории всеобщей литературы, но в 1861 году вместе с группой профессоров подал в отставку в знак протеста против реакционной политики правительства по отношению к студенчеству. Уйдя из университета, он занимался исключительно литературной и научной деятельностью. Им написано более 1200 научных работ, к числу которых относятся и исследования по истории, литературе, фольклору и этнографии южных и западных славян. Центральное место среди славистических трудов Пыпина занимает »Обзор истории славянских литератур«, написанный им при участии В.Д. Спасоевича (автора глав по истории польской литературы). »Обзор...« был издан в Санкт-Петербурге в 1865 году и сразу же привлек к себе внимание научной общественности. Второе, дополненное и переработанное издание (том 1-2, С.-Пб, 1879-1881) пользовалось широкой международной известностью и вскоре после публикации было переведено на немецкий, французский, чешский и лужицкий языки. »Обзор...« явился первым на русском языке сводным трудом, отразившим историю всех славянских литератур, начиная с древних времен и кончая эпохой национального Возрождения. Большое внимание уделялось освещению славянских литературных взаимосвязей и сопоставлению литератур зарубежных славян с русской и украинской литературами. Главам по истории литературы предшествовали очерки по славянской истории, этнографии и фольклору. Эти же принципы изложения материала были использованы и во втором, дополненном и переработанном издании, где история славянских литератур была доведена до 70-х годов XIX века. Для научной деятельности Пыпина характерно глубоко демократическое понимание смысла славянского вопроса, неприятие идей славянофилов и панславистов.

Он считал, что единство славянских народов может быть достигнуто лишь на основе равноправия, исходным моментом которого является »европейская цивилизация, а не странно понимаемые предания патриархальных времен или предрассудки обскурантизма«. ${ }^{24}$ Ученый отнюдь не идеализировал европейскую цивилизацию, однако считал, что подлинная народность литературы состоит не в противопоставлении славянства народам Европы, а в усвоении всего положительного, что выработано европейской культурой. Пыпин стремился включить историю славянских литератур в рамки славянской и мировой истории, подчеркивал органическую связь писателей и их творчества с религиозными течениями и их средой, истории литературы с историей умственной жизни. »Работы Пыпина по истории славянских литератур представляли собой не перечень имен и дат, как это бывало у других авторов; литература трактовалась как плод народной жизни, естественный результат развития идей и

${ }^{24}$ Пыпин А. Н. и Спасоевич В. Д. Обзор истории славянских литератур. С.-Пб, 1865. C. 530 
общественных отношений своего времени. Такой подход был в то время совершенно новым ${ }^{25}$

Эти принципы исследования литературного процесса Пыпин использует и при освещении истории словенской литературы. Изучая деятельность Трубара, Пыпин активно использовал работы словенских и немецких историков культуры, стараясь как можно полнее раскрыть характер протестантского движения в Словении. Пыпин совершенно справедливо утверждает, что настоящая история словенской литературы начинается со времен Реформации, когда в Штирию, Коринтию и Крайну проникло учение Лютера, Кальвина и Цвингли и нашло там своих горячих последователей, боровшихся за самостоятельную словенскую культуру и просвещение на народном языке. »Как вообще реформа, - утверждал Пыпин, - была отрицанием средневековой теократии и начинала более свободную критику, так в народной жизни она была возбуждением общественных сил. В Крайне начиналось то же оживление, какое было у чехов. И действительно, у народа малочисленного, совсем бесписьменного в течение девяти веков (c VII до XVI вв.) католического господства вдруг открывается энергичная работа, создается литературный язык, является ряд замечательных людей и трудов, научные знания времени применяются к славянским предметам, завязываются междуславянские связи, и движение от словенцев сообщается к хорватам и сербам Боснии и Приморья - начало, которому могла предстоять будущность«. ${ }^{26}$

Пыпин обращает внимание на то, что в кружок, сгруппировавшийся вокруг барона Унгнада, входили не только хорваты и словенцы, но и сербы, помогавшие в издании книг на кириллице. »Унгнад, — пишет Пыпин, - ревностно заботился о распространении протестантских книг, основал типографию и давал средства для издания целому кружку словенских протестантов, которые собрались здесь [в Германии, в Вюртембургском герцогстве - М.Б.] и печатали книги хорватские и краинские, глаголические, латинские и кирилловские. Этот кружок обнаружил замечательную деятельность, которая остается чрезвычайно любопытным эпизодом южнославянской литературы«. ${ }^{27}$

В этом »любопытном«, по словам Пыпина, эпизоде (в другом месте он назовет его »историческим поворотом«) в развитии словенской литературы Пыпин увидел качественно новые элементы самобытной словенской народной культуры эпохи позднего Средневековья. Его привлекают проблемы взаимодействия религиозного и светского мировоззрения, пробуждение национального самосознания, проявившееся в стремлении словенцев создать собственную церковь, собственную литературу на народном языке, открыть национальные школы. Рассматривая эти вопросы,

\footnotetext{
25 Лаптева Л. П. Исследования в области литературы и этнографии// Славяноведение в дореволюционной России. Изучение южных и западных славян. М. 1988. С. 250

${ }^{26}$ Пыпин А. Н., Спасоевич В. Д. История славянских литератур. Т. 1. С. 286

27 Там же. С. 286
} 
он вступает в полемику со своими предшественниками в этой области - Е. Копитаром и В. Клуном.

В целом Пыпин положительно оценивал деятельность Копитара, подчеркивал его заслуги перед славистической наукой: создание словенской Грамматики, издание Глаголиты Клоцианус, исследование Реймского евангелия, помощь В. Караджичу в издании сербского фольклора и создании сербской азбуки и правописания. Однако уже цитировавшееся выше высказывание о »духе религиозного фанатизма«, от которого - по утверждению Копитара — »бегут свободные музы«, вызвало у Пыпина активное неприятие. „Странно читать обвинение в фанатизме против переводчиков Библии, и как будто не были гораздо злейшими фанатиками те иезуиты, которые сжигали Библию, как будто иезуиты, преследуя протестантов, завоевывали свободу для муз!

Что же приобрели »музы« после победы иезуитов? Сами историки соглашаются, что словенская литература вплоть до настоящего столетия состояла почти из одних молитвенников и других церковных книг, то есть, иными словами, что литературы, собственно, вовсе не было, что »музы« вовсе ушли из Крайны«. ${ }^{28}$

Далее Пыпин возражает против высказывания Клуна, утверждавшего, что большинство словенского народа еще не чувствовало потребности в собственно литературных произведениях, чему довольно доказательств видим и теперь«. ${ }^{29}$

Пыпин объясняет отсутствие светской литературы именно диктатом церкви. И с этим утверждением можно согласится. Вспомним, хотя бы, каким яростным гонителем светской литературы был тот же Копитар.

После Пыпина обращение к литературе словенской Реформации не дало каких-либо серьезных результатов в течение ровно ста лет.

В 1979 году в Москве сотрудницей Института славяноведения и балканистики Академии Наук Ю. Д. Беляевой была опубликована монография »Литературы народов Югославии в Росии«, посвященное восприятию и изучению литератур югославских народов в России в последней четверти XIX-начале XX века. Монография эта была результатом многолетних научных изысканий автора, первым и, несомненно, удавшимся опытом обобщающего труда о восприятии и оценке югославских литератур в русской литературной и культурной среде. Структура монографии, избранная Ю.Д. Беляевой, позволила ей выделить узловые проблемы в развитии этих национальных культур, к числу которых относится и деятельность П. Трубара. Рассматриваемой проблеме автор смогла уделить всего несколько страниц, что и понятно, если учесть необычайно широкий круг исследуемых в книге материалов. Однако этого было достаточно, чтобы дать глубокий и всесторонний анализ словенской Реформации.

\footnotetext{
${ }^{28}$ Там же. С. 289

${ }^{29}$ Клун В. Словенцы. Очерк истории их словесности. С. 112
} 
»Насильственная германизация, - пишет исследовательница, - столетиями проводившаяся в словенских землях, надолго задержала развитие словенской письменности и литературы... »Настоящая история« словенской литературы, - как справедливо указывал Пыпин, - начинается в эпоху Реформации«. ${ }^{30}$ Автор рассматривает характеристику, данную Клуном и Пыпиным, а также монографию А. Соколова, упоминает о статье »Хорутанская литература«, написанной А. Будиловичем и предназначавшейся для антологии Р. В. Гербеля »Поэзия славян« и »Очерке развития литературы у словенцев« неизвестного автора, опубликованном в »Славянских известиях« за 1890 год.

»Во всех этих работах наибольшее внимание закономерно уделяется Приможу Трубару, идеологу словенской Реформации. Фигура чрезвычайно колоритная. Трубар справедливо рассматривается как родоначальник словенской литературы, как реформатор словенского литературного языка, его просветительская деятельность в целом — как начало новой эры в истории словенской национальной культуры... как пробуждение дотоле дремавших в народе сил и своеобразный мост в будущее - к дальнейшему развитию словенской национальной литературы«. ${ }^{31}$ В 1986 году в Москве вышла монография историка И.В. Чуркиной, также сотрудника Института славяноведения Российской Академии наук, »Русские и словенцы. Научные связи конца XVIII века - 1914 годщ, позже изданная на словенском языке (Rusko-Slovenski kulturni stiki od konca 18. stoletja do leta 1914. Ljubljana, 1995). Исследовательница успешно решает поставленную задачу: »Воссоздать на основе возможно более широкого конкретного материала, как архивного, так и печатного, историю русско-словенских научных связей в 19 веке«. ${ }^{32}$

Помимо работ, рассматриваемых Ю.Д. Беляевой, И. В. Чуркина останавливается на »Библиографических листах« П.И. Кеппена, приводит интересные сведения об университетских курсах по словенской литературе, которые читались в Петербургском (П. А. Лавров), Московском (Р. Ф. Брандрт), Киевском (Т.Д. Флоринский) и Варшавском (В.В. Макушев) университетах. В девяностые годы курс по славяноведению в Варшавском университете стал вести П.А. Кулаковский. »Текст курса по словенской литературе полностью сохранился в архиве В.Н. Кораблева, - сообщает исследовательница - ... С горячей симпатией Кулаковский писал о деятельности Трубара, считая ее важной не только для словенцев, но и для сербов и хорватов. Трубар »первый наметил литературный иллиризм,

\footnotetext{
${ }^{30}$ Беляева Ю. Д. Литературы народов Югославии в России. Восприятие, изучение, оценка. Последняя четверть 19, начало 20 века. М., 1979. С. 96-97

31 Там же. С. 99, 102

32 Чуркина И. В. Русские и словенцы. Научные связи конца 18 в. - 1914 год. М., 1986
} 
как бы предугадывая движение, которое обозначилось уже три столетия после егощ. ${ }^{33}$

Краткую, очень четкую характеристику деятельности П. Трубара дает в Краткой литературной энциклопедии (1972) известная словенистка М.И. Рыжова. Под влиянием исследованием М. Рупеля создает портрет словенского реформатора Л.К. Гаврюшина в первом томе »Истории литератур западных и южных славян« (М., 1997).

Устойчивый интерес к языку сочинений Трубара и его современников Ю. Далматина и С. Креля проявляет профессор Санкт-Петербургского государственного университета А.С. Герд. Им изданы две монографии — »Именное склонение в словенском языке 16 века« (С.-Пб, 2003) и »Местоимение в словенском языке 16 века«. Книги основаны на материале словенских старопечатных книг 16 века, которые сравниваются с другими (болгарскими, русскими и сербскими) памятниками древнеславянской письменности. Автор демонстрирует прекрасное знание специальной литературы на русском, немецком, английском и словенском языках. Важно отметить использование в указанных исследованиях лингвостатистических методов, что позволило показать особенности языка словенских писателей 16 века на широком языковом фоне.

За книгами последовали две новейших статьи петербургского ученого: »Модели словообразования имен существительных в словенских текстах 16 века« (Вестник Санкт-Петербургского университета, 2005. Серия 9, Вып. 3) и »К морфологии имен прилагательных в памятниках словенской письменности 16 века (Вестник Санкт-Петербургского университета, 2008. Серия 9, Вып. 4 номер 1).

Даже краткий обзор русских славистов, посвященных Трубару, позволяет утверждать, что в них проанализированы основные особенности словенской Реформации, показано огромное общественное и культурное значение деятельности Трубара и его последователей для развития словенского языка и словенского национального самосознания.

\section{SUMMARY}

Primož Trubar and His Work in Papers by Russian Slavonic Scholars

The first Russian records on Trubar date back to 1825. In "Bibliographic Leaves", P. I. Keppen wrote a short review of works written by Trubar, the Slovene reformer who published the first books in Slovene. Interest in Trubar's personality increased after a paper by Slovenian researcher V. Klun "The Slovenes; Essay upon Their History and Literature" appeared in the "Russkaya Beseda" journal (1859). In 1868, Moscow Slavonic scholar A. Devernois published Tubingen Acts of Vurtemberg

${ }^{33}$ Там же. С. 153 
Slavonic printing house (?) that presented a clear idea of circumstances faced by the developing Slovene Reformation.

In 1878, A. A. Sokolov published in Kiev his monograph entitled "Origin of Slovene Literature" concerning the leader of the Slovene Reformation. Sokolov considers Trubar one of the forefathers of Slovene literature and literary language, while his work as an enlightener is, according to Sokolov, the beginning of a new age in the history of Slovene national culture.

The outstanding Russian Slavonic scholar A. N. Pypin paid much attention to Trubar's personality in his "History of Slavonic Literatures", published in 1869. Among Russian philologists, he was the first who defined Slovene literary process in detail. He emphasized the significance of the Protestant movement advocating for an independent Slovene culture and enlightenment in the national language.

In the second half of the $20^{\text {th }}$ century, a specialist in literature studies, Yu. D. Belyaeva, discussed Slovene Protestantism, Trubar, and their interpretation by Russian scholars in her monograph "Literatures of Yugoslavian Peoples in Russia", 1979, as did the historian I. V. Churkina in "Russian Slovenes", 1986, 1995 in Slovene. M. I. Ryzhova's and L. K. Gavryushina's papers contain short reviews on the subject. The $16^{\text {th }}$ century-development of Slovene and the role of Trubar, Dalmatin, and Krel in this process are described in the monographs of Saint Petersburg University professor A. S. Gerd, "Noun Declension in $16^{\text {th }}$ Century Slovene", StP, 2003, and "Pronouns in $16^{\text {th }}$ Century Slovene", StP, 2005.

Even a short review of Russian Slavonic scholars' works on Trubar allows us to state that researchers have analysed the specifics of the Slovene Reformation and shown the immense public and cultural relevance of everything Trubar and his followers achieved in the development of Slovene language and Slovene national self consciousness. 